\title{
Promoting the Reading Culture towards Human Capital and Global Development
}

\author{
Olasehinde, M. O. ${ }^{1}$, Akanmode, O. A. ${ }^{1}$, Alaiyemola, A. T. ${ }^{1} \&$ Babatunde, O. T. ${ }^{1}$ \\ ${ }^{1}$ University Wide Courses Unit, Landmark University, Omu-Aran, Kwara State, Nigeria \\ Correspondence: Olasehinde, M. O., University Wide Courses Unit, Landmark University, Omu-Aran, Kwara \\ State, Nigeria. Tel: 803-382-1912. E-mail: olasehindemartha@yahoo.com
}

Received: February 20, 2015 Accepted: March 30, 2015 Online Published: May 28, 2015

doi:10.5539/elt.v8n6p194 URL: http://dx.doi.org/10.5539/elt.v8n6p194

\begin{abstract}
It is commonly agreed that a country cannot be fully developed without large-scale investment in her educational scheme since the breakthrough of a country is directly proportional to her educational level. Since the acquisition of effective reading skills has a positive effect on all school subjects, then reading is sine-qua-non for human capital and global development. Yet, it has been observed that many Nigerians today have a poor reading habit. Thus, this paper focuses on this poor reading habit among our people today and its causes. The paper is rounded off with suggestions as to what concerned stakeholders can do to develop and re-invent the reading culture in Nigeria.
\end{abstract}

Keywords: consequences, constrains, culture, development, reading, strategies

\section{Preamble}

Reading is a basic building block of learning while the reading culture is the philosophy of developing a progressive reading attitude. Reading hones the mind, making a person think logically and dispassionately. It prepares an individual for distinction in life. Reading is not just for the purposes of education in academic institutions. It is a lifelong activity. Reading, whether for pleasure or academic purposes is an essential habit which ensures greatness in a man's life. Writing on this Okebukola (2004) states that reading provides the tools for transmitting ideas to succeeding generations as well as the opportunity of partaking of the wisdom of past generations. On the other hand, Douglas (1961) maintains that children need to be proficient in reading for them to prosper in their academic work and carry out their duties as citizens of a self governing society. Writing on this Fosudo (2010), explains that a student who does not possess good reading skills tends to grow a negative attitude towards learning and this can even lead to his having self-esteem problems in later life. Similarly, Oke (1996) explains that people read for, amongst other reasons, self-development, feelings of self -importance, enjoyment, recreation and respect. While these facts hardly provide a subject for contention, many people are yet to imbibe this habit. Reading has been found to be the foundation of much enjoyment in life and at the same time it is strongly linked to occupational competence since students and employees in all fields of human endeavor must read in order to stay well-informed about developments in their areas of specialization. Thus, proficiency in reading has been seen to be totally crucial to success in life. Writing on this, Tracy (2008), maintains that reading is the only form of recreation which is also sine-qua- non for successful modern living. The attainment of effective reading skills has a positive influence on all academic subjects, whether in the humanities, arts or sciences. It is noteworthy that Cuba which has one of the highest rates of literacy in the world has a vibrant economy in spite of the decades of diplomatic conflicts it has had with a giant like U.S (Henry, 2004). It is thus understandable that the state of a country is affected by the fraction of its populace who are well-educated.

\section{Human Capital and Global Development}

Before we examine further the importance of reading, it is necessary to examine briefly what development is. According to Igwe $(2011$, p. 3), development refers to improving "people's lifestyle through improved, qualitative and functional education; incomes, skills development and fulfilled employment." He also maintained that development involves people being able to read and write. On the other hand, global development is seen as the development of a greater quality of life for humans, and well structured human capital enhancement is an asset for global development. 
Hershberg (1996, p. 1) sees human capital as "a concept or the education, skill levels, and problem-solving abilities that will enable an individual to be a productive worker in the global economy of the twenty-first century." Similarly, Enyekit et al. (2011, p. 64) see human capital as "a human capability and productivity engendered through knowledge and skills from vocational and technical education, training and experience and facilitated by an environment." According to them, the elements of human capital would include knowledge, skills, competences, attitudes and motivation which an enterprise or society engages in the fulfillment of its objectives and in the provision of goods and services. Thus, human capital development is something that must exist or happen for national development to take place. Human capital development presupposes investments, activities and processes that produce vocational and technical education, knowledge, skills, health or values that are embodied in people. Any effort to increase human knowledge, enhance skills, productivity and stimulate resourcefulness of individuals is an effort of human capital development (Erhurua, 2007, quoted by Enyekit et al. 2011, p. 64).

\section{Reading Culture}

The reading culture is one of the valuable assets which boost human generative powers of thinking for new innovations and development of personal talents and natural endowments. Behrman (2004), Magara and Batambuze (2005, quoted by Ruterana, 2012, p. 18) define the culture of reading as "an integrated pattern of reading behaviors, practices, beliefs, perceptions and knowledge." Also in their study on ways of creating the reading culture, they refer to the reading culture to mean "a culture where reading is part of the people's living and constitutes a habit that is shared by members of the society." The reading culture in African nations is viewed by many scholars as one way of "boosting students' academic excellence and lifelong learning" (Rosenberg, 2003; Magara \& Batambuze, 2005; Parry, 2005; Kachala, 2007; Kelechi, 2010; Commeyras \& Mazile, quoted by Ruterana, 2011, pp. 19-21). The reading culture is thus important since the sought for academic excellence cannot be achieved and sustained without the culture of keeping on reading for continuous self-improvement.

Reading gives us access to full participation in various activities in our modern society. It adds quality to our lives by giving us access to various cultures and cultural heritages. Reading empowers and emancipates us as citizens as well as brings people together as a nation. Igwe (2011, p. 1) quoting Sisulu (2004) stated further that "becoming a skilled and adaptable reader enhances the chances of success at school and beyond. Reading is not just for school, it is for life." This is so because the quality of age long or lifelong discoveries of new things through the boost of intuitive knowledge and its adaptability on various issues of life is enshrined in the reading culture.

Thus, reading in all its variety is vital to becoming better informed. It helps us to have a better understanding of ourselves as well as others. Leading world nations in Europe and America are proud of their endorsement of reading and see the high level of literacy in their society as being one of the major sources of their efficiency and growth. Without doubt, the economic, social and political health of our nation today depends on building literate citizens who are able to read widely and apply this practically for development. The development of Nigeria depends on the quality of its human resources. Osundare (2009) quoted by Igwe (2011, p. 1), states that;

Education is to society what the eye is to the body as well as what the rain is to the land in a fit of drought. It is the supreme light-giver, the breezy dawn after a night of suffocating darkness. It is what clears a path through the jungle, the compass that takes us ashore from the rough and clueless waters.

The relationship of reading ability to scholastic and life success is thus not open to dispute. When a poor reader makes no provision for achievement, he eventually is frustrated into a miserable state of failure. It is believed that those who failed in school usually have failed first in reading. An average graduate without a reading culture will most likely have a poor command of English. The reading culture then serves as a gateway to education which we regard as surest solution to ignorance; and this will often go beyond classroom level. It is also the gateway to employment in multinational corporations. According to Christos and Sugden (2000, p. 72),

Multinational corporations (MNC) or multinational enterprises (MNE) are organizations that own or control production or services facilities in one or more countries other than the home country.

For example, in the petrochemical corporations in Nigeria like SHELL, CHEVRON, AGIPP, ELF, etc., only competent heads who have cultivated a good personal reading habit can attract the jobs offered. In general terms, we can see reading as the reason behind the remarkable difference existing between the literacy level found in the developed parts of the world and the underdeveloped parts like Nigeria and most of the African countries. Therefore, our country needs to sensitize the present generation to the advantages and significance of reading and ensure that they have the literacy skills needed to function effectively in contemporary times. 


\section{Mini Research Conducted}

A mini descriptive survey research was carried out by the writers of this paper in April 2014, in order to ascertain the opinions of some Nigerians on the reading culture. The target population was all the staff and students of Landmark University, Omu-Aran, where the writers of this paper are working. The assumption Is that the information gathered would throw some light on the Nigerian situation, since the staff and students of the university have come from different parts of the Nation, with a negligible percentage coming from other nations.

Using the stratified random sampling technique in order to ensure that all departments were represented, one hundred (100) members of staff and two hundred (200) students were selected. The tool for the research was a 10-itemmed researcher designed questionnaire made of open ended and closed ended questions which was used to seek the opinions of the staff and students. This was personally administered by the researchers in order to deal with logistic problems on the spot and to guarantee high rate of return of the questionnaire. The data gathered for the study were here analyzed using frequency counts and percentages.

The findings of the study revealed that only $20 \%$ of adult Nigerians surveyed, read at least one book every month. In the same study, $40 \%$ stated that they liked reading, while $72 \%$ agreed that reading is the key to life-long learning. $60 \%$ rated their reading habits as generally very good, and $80 \%$ agreed that reading boosts human potentials. $55 \%$ see reading as a culture, while $56 \%$ agreed that good readers often read with purpose and focus which causes them to understand better. This is not good enough.

\section{The Reading Culture in Nigeria Today}

Reading, whether for academic purposes or for pleasure has been seen to be the key to lifelong learning. While this is hardly a subject for contention, yet, modern Nigeria is becoming bereft of well-read people. People just do not seem to read anymore, except reading daily newspapers and weekly magazines or glancing at labels found on manufactured items which they bought. This type of reading surely cannot be compared to reading one of Williams Shakespeare's or Chinua Achebe's books. The society has turned the electronic media, especially the internet, to a source of entertainment and education. This has paved way for the imbibing of mediocre ideas and language, making us to become a type of non-reading people. Creativity and ability to think for oneself is diminishing with the passage of time. Yet, the retention and application of knowledge comes from the reading widely of good books which further enrich a person mentally, spiritually and emotionally. Research has shown that many Nigerians hardly ever read; either because they are deficient in the skill, do not have the resources or just that they do not appreciate the importance of reading and the effect or consequences of not doing so. Many, especially students, read just for the purpose of passing examinations, those who have graduated from school hardly ever read at all and those who do read spend a very little part of their leisure time doing so. This lack of a prevalent culture of reading constitutes an effective barrier to Nigeria's growth and international competitiveness. This situation is as a result of certain constraints which are identified below.

\section{Constraints on the Reading Culture}

Many reasons have been adduced for this drop in reading. These are:

\subsection{Economic Inhibition}

Poverty has eaten deep into the fabrics of the society. Only a small percentage of the populace live above the poverty line. For example, in Nigeria, "the giant of Africa" with its plentiful natural resources, the minimum wage for government workers is eighteen thousand naira. This, to a great extent nagatively affects the reading habits of Nigerians. There is a dearth of money to buy books and pay school fees. Besides, the prices of books are rather on the high side and not within the reach of many. For example Chinua Achebe's books that used to cost about N150 naira, now cost as much as N700 in some shops. Many libraries cannot subscribe to relevant and up-to-date materials that foster the effective reading habit.

\subsection{Corruption}

This has a profound negative effect on the reading culture around the world, particularly, Nigeria. For example, quite a number of students would rather indulge in immoral acts than face their studies squarely. Instead, what is common in our institutions of higher learning are: exchanging sex for grades, selling of substandard textbooks at exorbitant prices, buying of examination grades and other examination malpractices. This is because many students see reading as an unproductive activity.

\subsection{Shortage of Reading Materials}

Students do not have variety of books to select from for reading and this hinders them from engaging in intensive and extensive reading. Willie (2008), states that schools and colleges need to be supplied with books that will 
sustain the reading interest of the students across the curriculum. Diangungu who echoes a similar view contends that "books provide the most effective means of disseminating and popularizing scientific and technological knowledge in the western countries, where nonfiction publications outnumber fiction." He maintained that developed countries have become technologically advanced primarily because books have become commonplace (Diangungu, 1980, cited in Biniakunu, 1990, p. 105). The situation in Africa is different. Here, as far as the production and reading of books are concerned, the picture is rather gloomy.

\subsection{Lack of Parental Encouragement}

In many homes, parents/guardians, many of who are products of the poor reading culture themselves make little or no effort at all in inculcating the reading culture into their children/ward. The first contact most children have with regular reading is in school and this is rather getting late. Ikpaahindi (2008) observes that as such children increase in age, they tend to see reading and other related activities as superhuman and out of their reach.

\subsection{Dearth of Libraries}

Libraries have a crucial role to play in promoting the reading culture. Yet, the role of libraries in developing the reading culture in the nation has been downplayed. The reality is that libraries (school and public) are either not existing at all or not performing their anticipated part. For instance in Nigeria, many states, local governments, and schools (public and private) have not complied with library provisions in the National Policy on Education (NPE). Besides, there is a dearth of public libraries. The few existing ones lack reading resources which can stimulate reading habits, due to lack of funds.

\subsection{Advent of Modern Technology}

Another reason is the low level of computer literacy among Nigerian citizens. Access to the internet is still poor and this hinders access to online reading resources such as e-books. The small percentage of Nigerians who are computer literate, particularly the youths are involved with the distractive and wrong application of the information and technology devices. This has produced some negative effects on the reading habits of such people. This internet obsession has caused many of our youths to waste valuable time surfing anti-moral and socially unfriendly websites. Instead of engaging in serious reading during their spare time, many people, especially youths, prefer to spend most of their time in cyber cafes browsing, playing video games, chatting with friends or drafting and sending fraudulent letters on the net, watching seasonal movies for several hours etc.

\section{Consequences of the Poor Reading Culture}

It is known that a good command of reading skills predisposes an individual to success at school and beyond. The connection between the reading ability on one hand and educational and life success on the other, is not debatable. Literacy is interrelated with the total educational process to the extent that educational success requires successful reading. Most of the time, students who failed academically have failed first in reading. According to Denchant (1977), "If the first button of a man's coat is wrongly buttoned, all the rest are certain to be crooked. Reading is the garment of education." A lot of students who would have contributed greatly to the nation's growth, when properly trained, drop out as a result of inadequate preparation for their examinations. Since a poor reader is not prepared to excel, he ends up in frustration and failure. An average graduate without the reading culture will not only posses a poor command of English, he will be technically inept, badly trained and, by and large, unsuitable for employment. The high failure rate in examinations, leading to the rise in the rate at which students drop out, as well as the incidence of half-baked graduates, etc., can affect a country socially, economically and politically. The much needed manpower produced by our tertiary institutions tends to fall below required standard as a result of this nonchalant attitude of students towards reading. Thus, the consequences of failure to possess the reading culture would be seen in the areas of education, career and general development.

\section{Benefits of Developing the Reading Culture in Nigeria}

Denchant (1977) maintained that when a man is literate, he has the ability to improve himself and make his life full, relevant, exiting and fulfilled. Education is a class leveler. With proper and thorough education; an individual can become anything he/she wants to become. Reading ensures and enhances the acquisition of knowledge and invariably projects man's skills and potentials. The absence of this limits his attaining the fulfillment of his dreams and career and relegates him to the background. However, in cases where corruption thrives such as is found in Nigeria, unqualified persons are employed in various job positions. It is difficult for such people to contribute to national development.

Writing on this, Osundare (2009) maintains that a country's level of development is a function of her level of mental and cultural evolution as well as the state of her educational development, which is dependent on the 
level of literacy of the population. Thus, without doubt, the level of development attained by any country is directly proportional to the level of literacy in the nation. Most of the problems experienced especially in African countries can be traced to the high level of illiteracy. Take for instance the matter of health. A person who is literate will not find it difficult to obtain information from various sources on how to be healthy. This is beneficial to the nation since only the healthy can contribute to the development of the country. Except a solution is found to the dwindling reading habit of Nigerians, the country will remain underdeveloped. Nigeria needs to raise its literacy level since literacy is the harbinger of development.

In reading lies the strength of a nation and has remained the pivot on which development rotates (Willie, 2009).

The habit of reading should be inculcated right from infancy and should be maintained throughout one's lifetime. This is necessary in order to grow natural talents which ultimately lead to enhancing the standard of output, making of skilled manpower and initiation of knowledge necessary for present-day economy. This way, up-coming and talented individuals can develop their capacities to the fullest so that they can contribute effectively to society.

As Nigeria struggles to achieve growth and development in economic, social and political sectors of the economy, it is crucial that students, who are the future leaders, be prepared to face the challenge of continuous national development. Economically, this will lead to the making of qualified manpower that will contribute positively towards improving the national income of the country. Politically, the nation will have vibrant electorates who will participate fully in the government of the nation. Socially, students will be able to contribute positively to the development of the culture instead of being a nuisance. Good reading culture will help the students to achieve more, this will boost their self-esteem and this will make tertiary institutions to turn out citizens who would be found worthy in character and learning.

\section{Strategies for Promoting the Reading Culture in Nigeria Today}

Strategy as defined by the Longman Dictionary of Contemporary English is a planned series of actions for achieving something. Therefore, developing an active reading culture involves planning and it takes time and effort. Strategies to turn Nigeria into a reading nation must be developed since acquiring the culture of reading can help to find solutions to the socio-economic and political problems facing the nation today leading to personal and national development. In 2011, the President, Goodluck Jonathan launched the "Bring back the Book" campaign and students were encouraged to read one novel per holiday. It was part of the deliberate plans of government to re-invent and encourage the reading and writing culture. Also, on $17^{\text {th }}$ March, $2014,{ }^{1}$ the president lamented the negative impact of the internet and social media on the reading and writing culture in the nation and maintained that the government may be compelled to re-launch the 'Bring Back the Book' programme which was earlier launched.

\subsection{General Strategies}

Among the general strategies to be employed are the following:

1) Improved funding for the establishment and equipment of libraries, particularly public libraries. Government at all levels should make grants available for the purchase of good literature books for children and adults. This should be backed up by a policy so as to make it effective.

2) Continued provision and access to books

3) Associating reading with pleasure

4) Excursions to libraries and book exhibitions

5) Encouraging user friendly policies and reader friendly environments in our libraries

6) Teachers should be models by reading in class and making time for students to read aloud in class.

7) Organization of reading clubs, reading competitions and reading days, thus young people can be encouraged to read by giving prizes to best readers.

8) Parental influence: Parents/guardians could encourage reading by buying books for their children/wards as birthday or other gifts and they should ensure that they read them especially at their leisure times or during the holidays instead of idling, watching T.V or playing all the time. Parents should also make a conscious effort to teach them how to read.

9) Authors should be encouraged financially by the government to write books.

10) Resuscitation of mobile library facilities as was done in the rural areas in the 1970s which has gone moribund since the 1980s. 
11) Mothers should inculcate reading habits into their children by reading to them for at least two hours, as from the infant age as being done in some advanced countries.

12) The employment of unqualified persons in job positions should be discouraged. The populace should be made to see the need for reading and acquiring the necessary knowledge which they can use to contribute to national development.

\subsection{Personal Strategies}

However, aside from what the government and society can do to improve on the reading culture, there are also individual or personal strategies that could be adopted in order to gain a greater reward from the time spent reading. The following strategies can be a tremendous help:

1) Purpose: Purpose determines a lot in life. Reading without purpose is like a driver who takes off without having a specific destination. It will be a total waste of valuable time reading without a specific purpose of what you stand to gain from the reading. Think about what you want to know. Ask yourself questions- Why am I reading this particular material? What do I stand to gain reading this? Will this reading add value to me at the end?

2) Focus: Focus can be defined as being totally committed to an assignment. It is to concentrate until your desired end is actualized. Without total concentration to what one is reading, it will end up a fruitless effort. Determine and know how deeply to study different types of materials like newspapers, magazines, articles, textbooks, etc. Also note whether to skim, scan, or speed read.

3) Guided questions: Reading with guided questions has to do with something that provides information and help you to form an opinion or that will help you to make decisions. Good readers do not take or accept everything they read hook, line and sinker. Set questions for your reading where none is provided.

4) Flexibility: Adopt a flexible reading speed. You should change to suit the reading material and the purpose of reading.

5) Memory enhancement: A good reader will employ memory enhancing devices that are unique to him/her. Individuals are different, so learn what way is the best for you to read and recall and go for it.

6) Attitudinal adjustment: Attitude determines altitude in all spheres of life, reading inclusive. Having attitudinal adjustments as a student is a necessary key to success and how far one will go in life. Attitude determines how well you do anything in life. Attitude indicates performance. Bringing the best out of reading depends on your attitude so be positive in your outlook especially towards reading Know yourself. Discover when is the best time for you to read and concentrate better. Stick to that knowledge and you will discover a world of difference in your reading habits.

\section{Conclusion}

Education today is a continuous process and a fundamental way of doing this is through reading at leisure. A reading nation is an informed nation. The habit of reading should be inculcated in youths right from the early stage and imbibed throughout one's life. A step in the right direction is the programme on Channels television tagged 'Channels Books Club', which is aimed at reviving the reading culture in the nation. In 2013, amongst others, it organized an essay competition for teenagers whereby they were to write a review after reading Chinua Achebe's Things Fall Apart. Also, there was the NGO, 'World Bank Book Club', which was also established to revive the reading culture among youths. President Goodluck Jonathan had spoken in an interview with the News Agency of Nigeria at a ceremony to mark the one year anniversary of the club's magazine "Readers Digest", that it was important to encourage youths to read so as to prepare them for the future challenges. He maintained that readers are leaders, so youths should read more instead of going about with earphones listening to music. There is no doubt that the world of reading is a world of wonders one might never have thought of until one plunges oneself headlong into it. When you make friends with books you will prefer their company ever after. You can also travel to exotic places sitting right in your house and can have all the feelings your role model felt while starting his or her first venture.

If we can succeed in inculcating the reading culture in Nigerian citizens, then there is hope that we can enjoy human capital development in the nearest future and truly become part of the ongoing global development.

\section{Acknowledgements}

We hereby acknowledge with gratitude all the staff and students of Landmark University Omu-Aran, Nigeria, who participated in the conduct of the mini-research reported in this write-up. We are also grateful to the Director of the University Wide Courses Unit of the University for providing the enabling environment and the 
non-academic staff of the Unit who assisted in the study.

\section{References}

Christos, P., \& Sugden, R. (2000). The nature of the transnational firm (p. 72). Routledge. Retrieved from $\mathrm{http}: / /$ www.amazon.com/Nature-Transnational-Firm-Christos-Pitelis/dp/0415167876

Denchant, E. (1993). Roots and Wings. In B. E. Cullian (Ed.), Pen Hand Children become Writers Network. International Reading Association.

Douglas, M. P. (1961). Primary school library and its services. Paris UNESCO.

Enyekit, E. O., Amaehule, S., \& Teerah, L. E. (2011). Achieving Human Capital Development in Nigeria through Vocational Education for Nation Building. Proceedings of the 2011 International Conference on Teaching, Learning and Change. IATEL Journal, 1(1), 63-69. Retrieved from http://www.hrmars.com/admin/pics/113.pdf

Federal Republic of Nigeria. (2004). National Policy on Education (4th ed.). Lagos: NERDC.

Fosudo, S. (2010). Reading as path to success: A lecture delivered at the College Library Day. Adeniran Ogunsanya College of Education, Otto/ Ijanikin, Lagos on February 24.

Hershberg, T. (1996). Human Capital Development: America's Greatest Challenge. ANNALS of the American Academy of Political Science, 1-2. Retrieved from http://www.cgp.upenn.edu/pdf/Human\%20Capital\%20 Development.pdf

Igwe, K. U. (2011). Reading Culture and Nigeria's Quest for Sustainable Development. Library Philosophy and Practice, 1-10. Omu Aran, Thomas Adewumi International College. Retrieved from http://www.webpages. uidaho.edu/ mbolin/igwe2.pdf

Ikpaahindi, L. N. (2008). Readership Promotion and National Development: The Librarian's View. In Readership Promotion and National Development: A collection of papers presented at the $7^{\text {th }}$ Nigeria International Book Fair and National Book Fairs. Lagos: The Nigeria Book Fair Trust.

Lorenzo, G. B. (2011). Development and Development Paradigms: A (Reasoned) Review of Prevailing Visions. EASYPol Resources for Policy Making - Food and Agricultural Organization of the United Nations, 2-6. Retrieved from http://www.fao.org/docs/up/easypol/882/defining_development_paradigms_102en.pdf

Okebukola, F. O. (2004). Reading: Key to lifelong development. A key note address delivered at the workshop on readership promotion campaign organized by the National Library Nigeria Press.

Ruterana, P. C. (2012). The Making of a Reading Society: Developing a Culture of Reading in Rwanda. Linkoping, Linkoping University, 1(1), 63-69.

Willie, E. (2009). Reading Culture and Value Reorientation. In Readership Promotion and National Development: A collection of papers presented at the 7th Nigeria International Book Fair and National Book Fairs. Lagos: The Nigeria Book Fair Trust.

\section{Copyrights}

Copyright for this article is retained by the author(s), with first publication rights granted to the journal.

This is an open-access article distributed under the terms and conditions of the Creative Commons Attribution license (http://creativecommons.org/licenses/by/3.0/). 